\title{
Optimization of an Activity Assay of Coprinus Cinereus Peroxidase
}

\author{
Bing Xue Dong', Yu Hong Zhang ${ }^{1}$, Gang Li $^{2}$, Jin Tao Fang ${ }^{3}$, Ji Huan Zheng1, Run Qian \\ Mao $^{1 *}$. \\ ${ }^{I}$ Guangdong Institute of Applied Biological Resources, Guagdong, China, ${ }^{2}$ Sun Yat-Sen University, Guangzhou, \\ China, 3Nanyang Normal University, Nanyang, China.
}

\begin{abstract}
To seek a simple, rapid and sensitive Coprinus cinereus Peroxidase (CIP) activity assay, a convenient one-factor-ata-time (OFAT) method and a response surface methodology (RSM) were used. The recombinant CIP expressed in Pichia pastoris was purified with the Ni-NTA spin column. Based on the results of catalytic efficiency $\left(k_{\mathrm{ca}} / K \mathrm{~m}\right)$ analysis, 2,2'-azinobis (ethylbenzthiazoline -6-sulfonate) (ABTS) was selected as the optimal enzyme substrate. Results of the OFAT method showed that enzymatic reaction performed in $0.1 \mathrm{~mol} / \mathrm{L}$ sodium acetate (pH 5.0) buffer in a 200- $\mu$ l reaction mixture containing $0.5 \mathrm{mmol} / \mathrm{L}$ ABTS, $10 \mathrm{mmol} / \mathrm{L}$ hydrogen peroxide $\left(\mathrm{H}_{2} \mathrm{O}_{2}\right), 49.7 \mathrm{ng} \mathrm{CIP}$ at $25^{\circ} \mathrm{C}$ gave an average CIP activity of $88 \mathrm{U} / \mathrm{mL}$. The ABTS and $\mathrm{H}_{2} \mathrm{O}_{2}$ concentrations were then further optimized to improve the sensitivity of the assay. To do that, RSM was conducted through central composite design, and a reduced quadratic model with good fit regression equation was generated. ANOVA analysis of this model indicated that the concentrations of $A B T S$ and $\mathrm{H}_{2} \mathrm{O}_{2}$ and their interaction had significant impact on the assay sensitivity. The optimal reaction mixture was determined to include an initial ABTS concentration of $0.82 \mathrm{mmol} / \mathrm{L} 49.7 \mathrm{ng}$ CIP and $16.36 \mathrm{mmol} / \mathrm{L} \mathrm{H}_{2} \mathrm{O}_{2}$, and the activity under this condition was determined to be $138.89 \mathrm{U} / \mathrm{mL}$.
\end{abstract}

Key words: enzymatic activity assay, one-factor-at-a-time (OFAT) method, response surface methodology (RSM), Coprinus cinereus peroxidase (CIP)

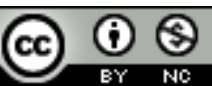

*Author for correspondence: 102438816@qq.com 


\section{INTRODUCTION}

Peroxidases (EC 1.11.1.7) are heme-containing enzymes that are widely distributed in animals, plants and microorganisms. They oxidize a variety of organic and inorganic compounds with the presence of hydrogen peroxide ${ }^{1,2,3,4}$. Their powerful oxidizing ability makes peroxidases very useful in many fields, including analytical chemistry, immunochemistry, and biosensor construction. In addition, they have great potential and prospect in the textile, paper and pulp bleaching industries ${ }^{1,5}$. Although peroxidases are important in many industries, it is difficult to produce these enzymes in large scale, because most of the peroxidases are isolated from plants. The production and properties of these enzymes are restricted by geographical and climate conditions. A fungal peroxidase secreted from Coprinus cinereus was first isolated and characterized by Shinmen et al. ${ }^{6}$. This peroxidase (CIP) has high activity and broad substrate specificity similar to that of horse radish peroxidase (HRP), although there is less than 10\%-16\% sequence similarity between CIP and HRP, and thus has attained considerable attention since it was isolated ${ }^{7,8}$. CIP has higher thermostability than $\mathrm{HRP}^{9,10}$. It has been used successfully to remove phenolic compounds from wastewater ${ }^{11-16}$, to degrade benzene homologs and derivates ${ }^{17,18}$, to decolourate dyes ${ }^{19-21}$, and to produce functional polyaromatics ${ }^{22-26}$. CIP can also be used as cleaners ${ }^{27}$ and biosensors ${ }^{28}$. Therefore, from a commercial viewpoint, CIP is a good candidate for replacing HRP in industry applications, and has broad market prospect. Unfortunately, a standard CIP activity assay is not available so far.

Because CIP can catalyze a wide range of substrates, there are several methods to measure CIP activity, such as the ABTS method ${ }^{23,29,30}$, the phenol method ${ }^{17,21,28,31}$, the guaiacol method ${ }^{32}$, the pyrogallol method ${ }^{12}$, and the o-phenylenediamine method $^{33}$. When measuring specific activity, researchers use different assay mixtures, including different substrates, different types of buffers, different $\mathrm{pH}$, different temperature, and different concentration of substrates according to their needs, which lead to difficulties in comparing the activity of CIPs from multiple sources, and thus hinder their applications in the industry. Phenol, guaiacol and ophenylenediamine are slightly soluble in water, and the preparation of substrate solutions and reaction mixtures require much effort. Furthermore, phenolic compounds (i.e. guaiacol, phenol and pyrogallol) and o-phenylenediamine are toxic, insensitive for the CIP activity assay, and the residue reaction mixture needs to be treated before release to the environment. Hence, there is an urgent need to develop a simple, rapid and sensitive CIP activity assay with good reproducibility.

CIP activity is greatly affected by $\mathrm{pH}$, buffer, temperature, type of substrate, and substrate and $\mathrm{H}_{2} \mathrm{O}_{2}$ concentrations. The widely accepted one-factor-at-a-time (OFAT) method for optimizing enzymatic activity assays involves varying one parameter at a time while keeping the other parameters constant. This technique is time-consuming, and ignores the interactions among different parameters, so it may lead to wrong conclusions ${ }^{21,34}$. An assay with orthogonal design can evaluate the interactions among different parameters accurately, but requires too much experimentation, and is time-consuming and labor intensive.

Response surface methodology (RSM) is a useful mathematical and statistic method to overcome these difficulties. RSM requires minimal experimentation, but can help researchers to optimize conditions from multiple variables rapidly and efficiently, and to provide sufficient information that leads to sound results ${ }^{34-37}$. RSM has been successfully applied in areas of food science research ${ }^{38-40}$, enzyme production from

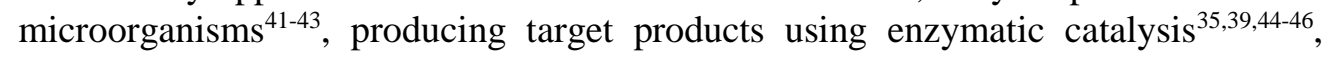


biodiesel production ${ }^{47}$, and dye decoloration ${ }^{21,34,48}$. To the best of our knowledge, there has been no report on the optimization of enzymatic activity assay using RSM. As part of the optimization process of the enzymatic activity assay, the optimal substrate was determined by comparing the CIP catalytic efficiencies $\left(k_{\mathrm{cat}} / K_{\mathrm{m}}\right)$ of different substrates, and ABTS was selected as the optimal substrate for the assay. Then, to investigate the interaction between ABTS and hydrogen peroxide concentrations and its effect on enzymatic activity assay, both the OFAT method and the RSM were used to improve the sensitivity of the assay using the specificity of the assay as the response value.

\section{MATERIAL AND METHODS}

\section{Chemicals}

All chemicals and reagents were of analytical grade, [2,2'azinobis(ethylbenzthiazoline-6-sulfonate)] (ABTS), phenol, 2,6-Dimethoxyphenol (2,6-DMP), guaiacol, and 2,4-dichlorophenol (2,4-DCP) were obtained from SigmaAldrich (St. Louis, MO, USA). Peptone and yeast extract were purchased from Oxoid (Basingstoke, England). Ni-spin column was obtained from QIAGEN (Hilden, Germany). Other chemicals were purchased from Shanghai Sangon (Shanghai, China).

\section{Strain, media and growth condition}

Engineered strain P. pastroi CIP/GS115, harboring the CIP gene with P. pastroi codon bias integrated into the Pichia genome, was used to produce recombinant CIP efficiently. Solid YPD (1\% yeast extract, $2 \%$ peptone, $1 \%$ glucose, and $1 \%$ agar) was used to produce single clone inoculum. BMGY (1\% yeast extract, $2 \%$ peptone, $1.34 \% \mathrm{YNB}, 0.1 \mathrm{~mol} / \mathrm{L}$ phosphate buffer $\mathrm{pH} 6.0,0.4 \mathrm{mg} / \mathrm{L}$ biotin and $1 \%$ glycerol) and BMMY (the same as BMGY, except that $0.5 \%$ methanol was used instead of $1 \%$ glycerol) were used to induce protein expression. Protein was induced at $28^{\circ} \mathrm{C}$, while at other times P. pastroi CIP/GS115 was grown at $30^{\circ} \mathrm{C}$.

\section{Production and purification of recombinant CIP}

Single clones of CIP/GS115 were prepared on YPD agar plate. Cells from single clone were inoculated into $5 \mathrm{~mL}$ of BMGY medium in a $20-\mathrm{mL}$ screw cap test tube. Cultures were grown at $30^{\circ} \mathrm{C}$ with agitation $(220 \mathrm{rpm})$ overnight, and then transferred to 500-ml shake flask containing $100 \mathrm{ml}$ BMGY medium sealed with a four-layer sterile gauze and continued to culture with agitation $(220 \mathrm{rpm})$ at $30^{\circ} \mathrm{C}$.When OD600 of the culture reached 4.0-6.0, cells were centrifuged at 4,000 g for $5 \mathrm{~min}$, and resuspended in BMMY medium to an OD600 of 10. Methanol was added to the culture at a final concentration of $0.5 \%$ every $24 \mathrm{~h}$ to maintain induction, and cultivation continued at $28^{\circ} \mathrm{C}$ for 5 days with agitation. After induction, the extracellular CIP with a polyhistidine (6×His) tag was purified using Ni NTA spin column according to the instructions of the manufacturer in a cold room.

\section{Determination of the concentration of the recombinant CIP}

The purity of recombinant CIP was estimated by sodium dodecyl sulfate polyacryl amide gel electrophoresis (SDS-PAGE). Protein concentration was determined using Nanodrop 2000 ultraviolet spectrophotometer (ThermoFisher, CA, USA) at $280 \mathrm{~nm}$ $\left(\varepsilon=1.597 \times 104 \mathrm{~L} \cdot \mathrm{mol}^{-1} \mathrm{~cm}^{-1}\right) . \quad \mathrm{NPI}-500\left(50 \mathrm{mmol} / \mathrm{L} \mathrm{NaH}{ }_{2} \mathrm{PO}_{4}, 300 \mathrm{mmol} / \mathrm{L} \mathrm{NaCl}\right.$, $500 \mathrm{mmol} / \mathrm{L}$ imidazole) was used as the blank control.

\section{Selection of optimal substrate according to kinetic parameters}


To investigate the substrate specificity of the purified recombinant CIP, 5 substrates were selected, and the kinetic parameters (Km and kcat) of the recombinant enzyme were determined by assaying the enzymatic activity in the $0.1 \mathrm{~mol} / \mathrm{L}$ sodium acetate $(\mathrm{NaAC})$ buffer $(\mathrm{pH} 5.0)$ at $25^{\circ} \mathrm{C}$ with ABTS ranging from $0.0625-1.5 \mathrm{mmol} / \mathrm{L}$, phenol ranging from $0.125-7.5 \mathrm{mmol} / \mathrm{L}$, guaiacol ranging from $0.25-5 \mathrm{mmol} / \mathrm{L}, 2,4-$ DCP ranging from $0.125-12.5 \mathrm{mmol} / \mathrm{L}$, or $2,6-\mathrm{DMP}$ ranging from $0.0625-2.95$ $\mathrm{mmol} / \mathrm{L}$ as the substrate. A total of $0.63 \mathrm{mmol} / \mathrm{L}$ 4-aminoantipyrine (4-AAP) was added to the assay mixture when using phenol as substrate. Values for the maximum velocity and half-saturation coefficient $(\mathrm{Km})$ were determined by fitting the data of the substrate concentration vs. the initial velocity of each reaction to the nonlinear regression of the Michaelis-Menten equation. Kinetic analyses by curve fitting were performed with the Graphpad prime 5 software. The substrate with the highest $\mathrm{Kcat} / \mathrm{Km}$ value was selected as the best substrate.

\section{One factor at a time method}

CIP activity was measured in a microplate reader Bio-Rad EXL 800 with ABTS $\left(\varepsilon_{420 \mathrm{~nm}}=36,000 \mathrm{M}^{-1} \mathrm{~cm}^{-1}\right)$ as the substrate. One unit of CIP activity was defined as the amount of CIP required to produce $1 \mu$ mol ABTS cation per min from ABTS under specified conditions.

Enzyme amount of $49.7 \mathrm{ng}$ was selected according to previous experience, since excess enzyme might lead to the absorbance value to exceed the machine reading range. Assay of mixture optimization was carried out by changing an independent variable while fixing the others at certain levels. $\mathrm{PH}$, temperature, buffer, and $\mathrm{H}_{2} \mathrm{O}_{2}$ and ABTS concentrations play crucial roles in the CIP activity measurement. Therefore, these parameters were optimized using the OFAT method.

The experiments were conducted in microplates containing $200 \mu \mathrm{L}$ mixture containing ABTS, buffer, CIP, and $\mathrm{H}_{2} \mathrm{O}_{2}$, which were placed on the microplate reader at different experimental conditions as bellow:49.7 ng of CIP, ABTS concentrations $(0.063-1.5 \mathrm{mmol} / \mathrm{L}), \quad \mathrm{H}_{2} \mathrm{O}_{2}$ concentrations $(0.05-50 \mathrm{mmol} / \mathrm{L})$, temperature $\left(10-60^{\circ} \mathrm{C}\right)$ and $\mathrm{pH}(2.2-9.0)$. The buffers used in optimal $\mathrm{pH}$ tests were the Mcllvaine's citrate-phosphate ( $\mathrm{pH}$ 2.2-2.6) and the Britton-Robinson buffer $(\mathrm{pH}$ 3.0-9.0). Furthermore, different buffers, including the Mcllvaine's citrate-phosphate buffer, the Britton-Robinson buffer and $0.1 \mathrm{~mol} / \mathrm{L}$ NaAC were selected and adjusted to $\mathrm{pH} 5.0$ to seek for the most sensitive one. Table 1 lists different experimental conditions for the OFAT method. All experiments were conducted in triplicate and average values were reported.

Table 1 Experimental conditions used in the OFAT method

\begin{tabular}{|c|c|c|c|c|c|}
\hline Parameter & $\mathrm{pH}$ & $\begin{array}{l}\mathrm{H}_{2} \mathrm{O}_{2} \\
(\mathrm{mmoll} / \mathrm{L})\end{array}$ & $\begin{array}{l}\text { Temp } \\
\left({ }^{\circ} \mathrm{C}\right)\end{array}$ & $\begin{array}{l}\text { ABTS } \\
(\mathrm{mmol} / \mathrm{L})\end{array}$ & Buffer \\
\hline Effect of Ph & $2.2-9.0$ & 0.1 & 25 & 0.5 & A B \\
\hline Effect of Buffer & 5.0 & 0.1 & 25 & 0.5 & $\mathrm{ABC}$ \\
\hline Effect of $\mathrm{H}_{2} \mathrm{O}_{2}$ conc & 5.0 & $0.05-50$ & 25 & 0.5 & $\mathrm{C}$ \\
\hline Effect of temperature & 5.0 & 0.1 & $10-60$ & 0.5 & $\mathrm{C}$ \\
\hline Effect of ABTS conc & 5.0 & 0.1 & 25 & $0.063-1.5$ & $\mathrm{C}$ \\
\hline
\end{tabular}

A: Mcllvaine's citrate-phosphate buffer, B: Britton-Robinson buffer, C: NaAC Buffer 


\section{Response surface analysis}

A response surface methodology (RSM) with a two-factor (i.e. ABTS concentration and $\mathrm{H}_{2} \mathrm{O}_{2}$ concentration) and five-level (Table 2) central composite design (CCD) was carried out to improve the sensitivity of the CIP activity assay according to the design of the statistical software package "Design Expert 8.05", leading to 13 different experiments in random with 5 replicates at the center point. Other parameters, including a temperature of $25^{\circ} \mathrm{C}, 0.1 \mathrm{~mol} / \mathrm{L} \mathrm{NaAC}$ buffer (pH 5.0), and 49.7 ng CIP, were kept constant, all the experiments were carried out in triplicate. The level of different variables with code and actual value and average values of activity were reported in Table 2. The program of "Design Expert 8.05" was used to analyze the experimental design and results.

Table 2 central composite design with two independent variables

\begin{tabular}{|c|c|c|c|c|c|}
\hline \multirow{2}{*}{ Run } & \multicolumn{2}{|c|}{ ABTS $(\mathrm{mmol} / \mathrm{L})$} & \multicolumn{2}{|c|}{$\mathrm{H}_{2} \mathrm{O}_{2}(\mathrm{mmol} / \mathrm{L})$} & \multirow{2}{*}{ Activity ( $(\mathrm{U} / \mathrm{mL})$} \\
\hline & Coded value & Actual value & Coded value & Actual value & \\
\hline$\overline{1}$ & 0 & 0.5 & 0 & 10 & 80.926 \\
\hline 2 & $-\gamma$ & 0.05 & 0 & 10 & 41.667 \\
\hline 3 & 0 & 0.5 & 0 & 10 & 91.269 \\
\hline 4 & 0 & 0.5 & 0 & 10 & 82.407 \\
\hline 5 & 1 & 0.82 & -1 & 3.64 & 65.185 \\
\hline 6 & 1 & 0.82 & 1 & 16.36 & 129.63 \\
\hline 7 & 0 & 0.5 & $-\gamma$ & 1 & 27.593 \\
\hline 8 & $\gamma$ & 0.95 & 0 & 10 & 135.741 \\
\hline 9 & 0 & 0.5 & $\Gamma$ & 19 & 102.037 \\
\hline 10 & 0 & 0.5 & 0 & 10 & 95.371 \\
\hline 11 & 0 & 0.5 & 0 & 10 & 90 \\
\hline 12 & -1 & 0.18 & -1 & 3.64 & 31.852 \\
\hline 13 & -1 & 0.18 & 1 & 16.36 & 47.593 \\
\hline
\end{tabular}

\section{RESULTS AND DISCUSSION}

Production, purification and concentration measurement of recombinant CIP The expression of recombinant CIP was induced with methanol, and the protein was then purified using the Ni-NTA spin column. On SDS-PAGE gel, a clear band of estimated size of $43 \mathrm{kDa}$ was observed (Fig.1), and this size was in accordance with the predicted molecular mass. The concentration of purified recombinant CIP was $14.916 \mathrm{mg} / \mathrm{mL}$. 


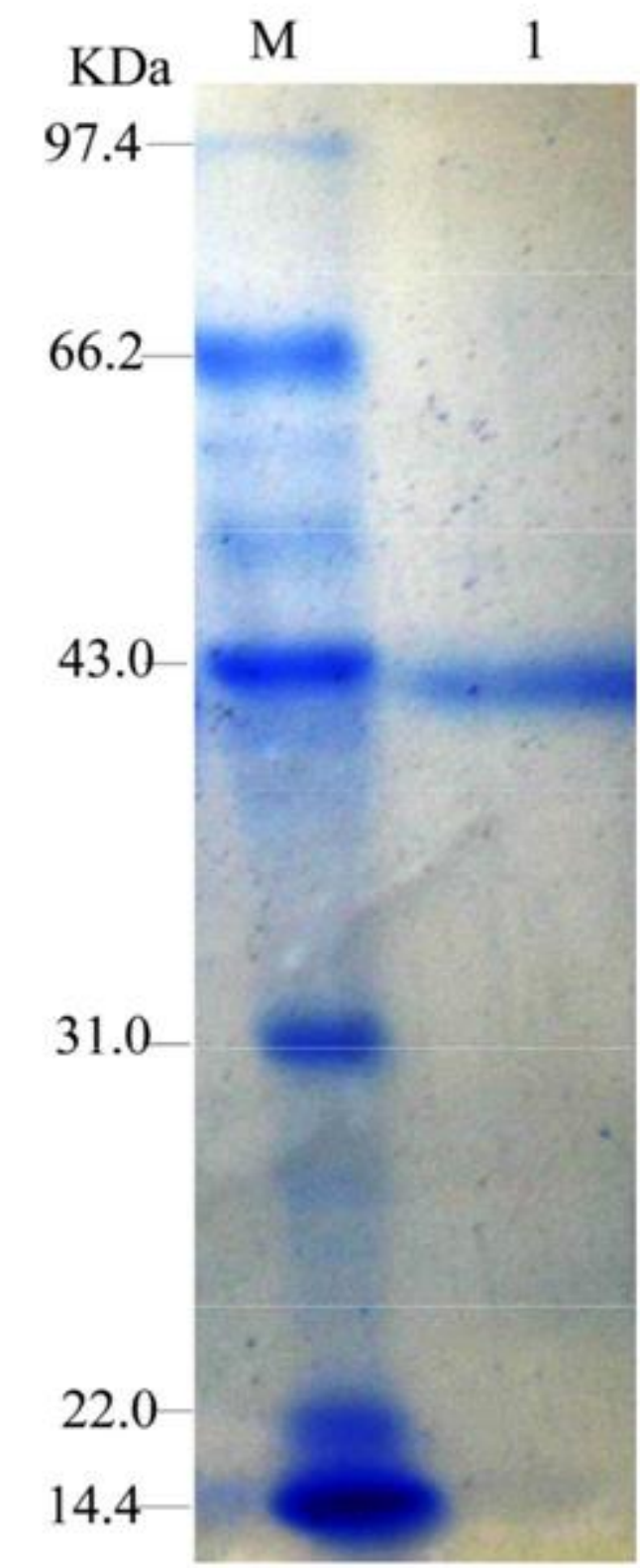

Figure 1. SDS-PAGE analysis of the purified recombinant CIP. M, standard protein molecular mass markers (TaKaRa, sizes in kilodaltons are indicated on the left); Lane 1, recombinant CIP purified by Ni-NTA spin column.

Selection of optimal substrate

In general, the catalytic efficiency $\left(k_{\mathrm{cat}} / K_{\mathrm{m}}\right)$ is considered as a measurement of the enzymatic specificity.

The initial reaction rates with various substrate concentrations were measured, and the kinetic parameters for the enzymatic activity of the recombinant CIP using different substrates were summarized (Table 3 ).

ABTS was the best substrate with the highest catalytic efficiency, followed by guaiacol, 2, 6-DMP, 2,4-DCP and phenol. We also found that the minimal time to convert various amount of 2,4-DCP or phenol into steady brownish red products was 30-65 min using $9.94 \mu \mathrm{g}$ enzyme, while the minimal time to convert various amount of 2,6-DMP into steady brownish red products was 5-10 min using $4.97 \mu \mathrm{g}$ enzyme. Using ABTS as substrate saved time and effort, and it was more water soluble and less toxic than other substrate. Therefore, ABTS was used as the substrate for further experiments. 
Table 3 Kinetic parameters and specific activity of CIP with different substrate

\begin{tabular}{llll}
\hline Substrate & Km $(\mathrm{M})$ & Kcat $(\mathrm{S}-1)$ & Kcat $/ \mathrm{Km}(\mathrm{S}-1 \mathrm{mM}-1)$ \\
\hline ABTS & $62.80 \pm 7.771$ & $17.190 \pm 0.314$ & 0.274 \\
$2,6-\mathrm{DMP}$ & $711.00 \pm 9.403$ & $0.122 \pm 0.006$ & $1.718 \times 10-4$ \\
Guaiacol & $150.200 \pm 3.047$ & $0.200 \pm 0.005$ & 0.001 \\
Phenol & $240.200 \pm 5.090$ & $0.003 \pm 0.001$ & $1.249 \times 10-5$ \\
2,4-DCP & $1494.000 \pm 128.400$ & $0.054 \pm 0.0001$ & $3.614 \times 10-5$ \\
\hline
\end{tabular}

Effects of $p H$ and buffer on CIP activity

$\mathrm{PH}$ plays crucial roles in enzyme activity assays. It influences not only the dissociative state of the substrate and the enzyme, but also the structure of the catalytic active center of the enzyme. Most enzymes are active only within a narrow $\mathrm{pH}$ range, and drastic changes in $\mathrm{pH}$ often lead to denaturation of the enzyme ${ }^{44}$. To investigate the effect of $\mathrm{pH}$ on enzyme activity, experiments were performed at $25^{\circ} \mathrm{C}$ and $\mathrm{pH}$ conditions ranging from 2.2 to 9.0 with $0.5 \mathrm{mmol} / \mathrm{L}$ ABTS, $0.1 \mathrm{mmol} / \mathrm{L}$ $\mathrm{H}_{2} \mathrm{O}_{2}$, and $49.7 \mathrm{ng}$ purified recombinant enzyme (Fig. 2A). The optimum assay $\mathrm{pH}$ was determined to be 5.0. The enzyme activity increased with the increase in $\mathrm{pH}$ between 2.2 and 5.0. However, CIP activity decreased notably at above pH 5.0.

Buffer type also affected CIP activity assay greatly. Three types of buffer was used in this study, including $0.1 \mathrm{~mol} / \mathrm{L}$ sodium acetate $(\mathrm{NaAC})$ buffer, the BrittonRobinson buffer and the Mcllvaine's citrate-phosphate buffer adjusted to $\mathrm{pH}$ 5.0. The sensitivity of the enzymatic activity assay was the highest in $0.1 \mathrm{~mol} / \mathrm{L} \mathrm{NaAC}$ buffer, followed by the Britton-Robinson buffer and the Mcllvaine's citratephosphate buffer (Fig. 2B). Therefore, $0.1 \mathrm{~mol} / \mathrm{L} \mathrm{NaAC}$ buffer ( $\mathrm{pH} 5.0$ ) was selected 


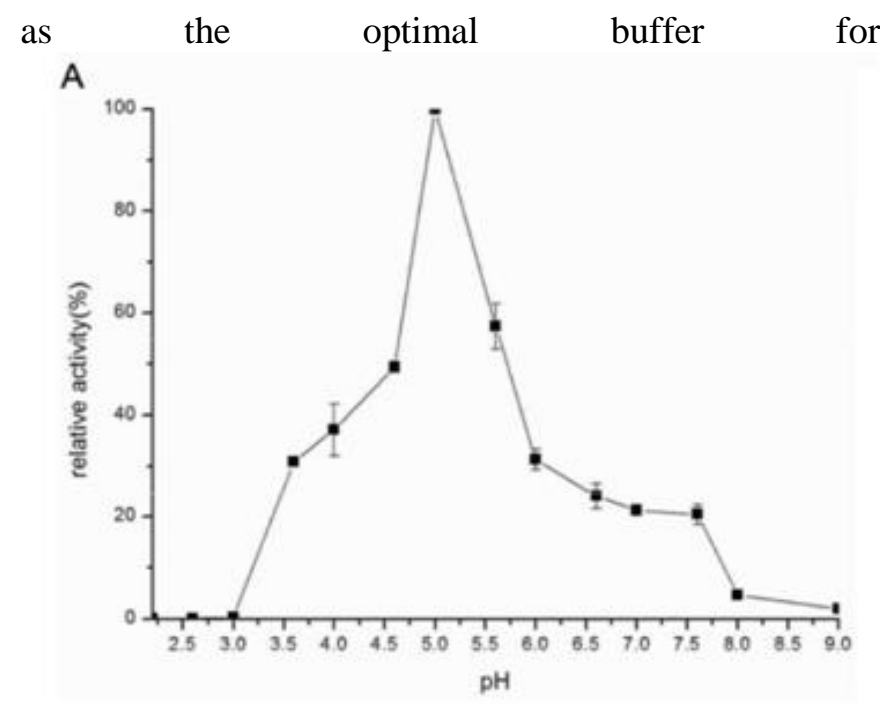

B

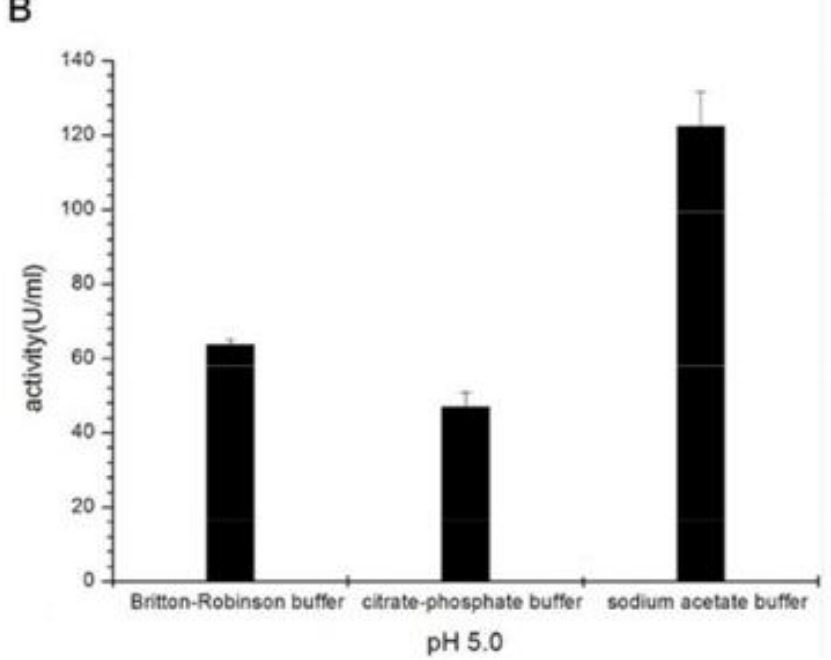

Figure 2. Effects of $\mathrm{pH}(\mathrm{A})$ and types of buffer (B)on CIP activity. Data points are the average of triplicate measurements. Error bars represent $\pm 1 \mathrm{SD}$.

Effect of temperature on CIP activity

The effect of temperature on enzyme activity was measured and summarized (Fig. 3). The CIP activity increased with temperature increase until $25^{\circ} \mathrm{C}$, above which the activity decreased significantly, because high reaction temperature led to irreversibly denatured CIP, whereas low temperature slowed down the reaction due to a lack of energy for additional substrates to enter into transition state ${ }^{44}$. According to our result, $25^{\circ} \mathrm{C}$ was selected as the optimal reaction temperature. 


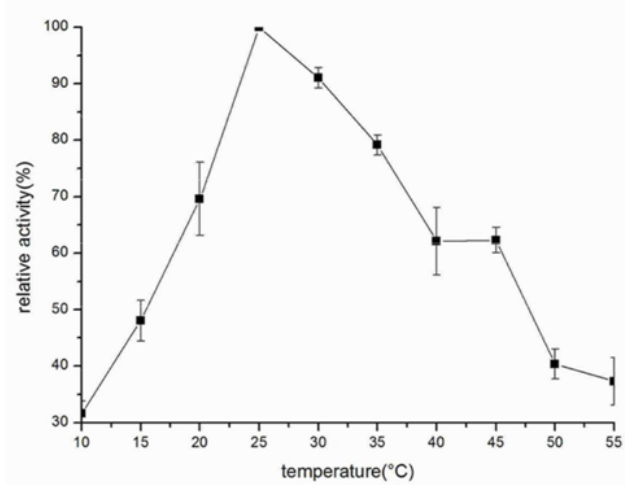

Figure 3. The effect of temperature on CIP activity. Data points are the average of triplicate measurements. Error bars represent \pm 1 SD.

Effects of ABTS concentration and $\mathrm{H}_{2} \mathrm{O}_{2}$ concentration on enzymatic activity

Substrate concentration significantly affects the enzyme activity. In general, activity increases with the increase in substrate concentration before the enzyme is saturated, and then keeps constant and even decreases slowly. Experiments were performed to investigate the effects of ABTS and $\mathrm{H}_{2} \mathrm{O}_{2}$ concentrations on enzyme activity (Fig. 4). The optimal ABTS concentration was $0.5 \mathrm{mmol} / \mathrm{L}$, and the enzymatic activity drastically increased when the ABTS concentration increased from 0 to $0.3125 \mathrm{mmol} / \mathrm{L}$. The enzymatic activity increased slowly when the ABTS concentration was between 0.3125 and $0.5 \mathrm{mmol} / \mathrm{L}$, and decreased slowly over 0.5 $\mathrm{mmol} / \mathrm{L}$ (Fig. 4A).
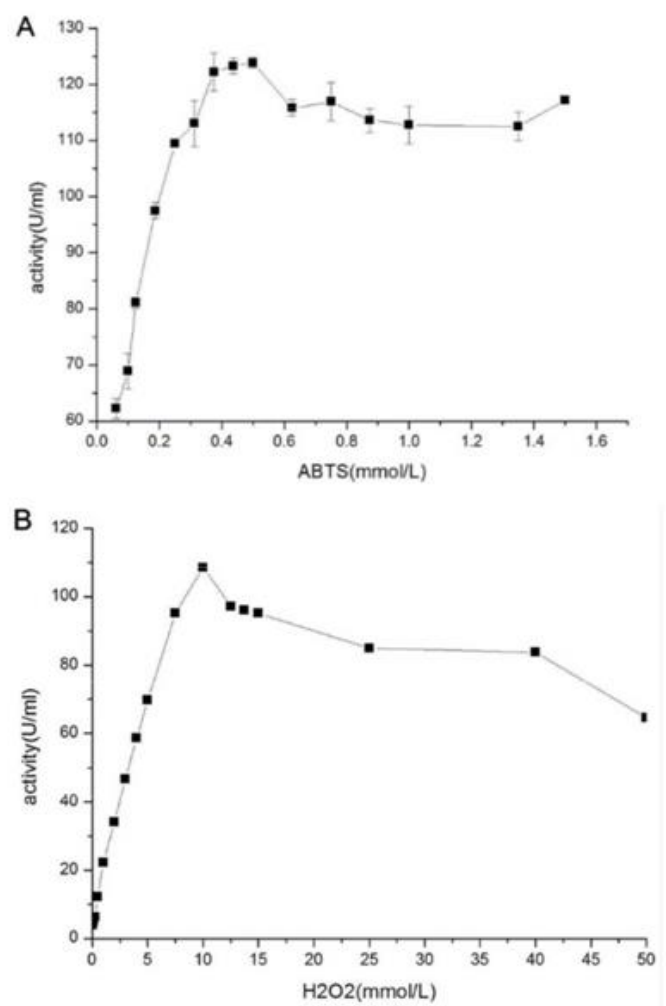

Figure 4. The effects of ABTS (A) concentration and $\mathrm{H}_{2} \mathrm{O}_{2}(\mathrm{~B})$ concentration on CIP activity. Data points are the average of triplicate measurements. Error bars represent $\pm 1 \mathrm{SD}$.

$\mathrm{H}_{2} \mathrm{O}_{2}$ is essential for CIP activity. The optimum $\mathrm{H}_{2} \mathrm{O}_{2}$ concentration was determined to be $10 \mathrm{mmol} / \mathrm{L}$, above which the enzymatic activity decreased gradually (Fig. 4B). 
Previous studies have shown that excess hydrogen peroxide is suicidal, resulting in heme destruction, protein oxidation and CIP inactivation ${ }^{3,49,50}$. It has been reported that high concentrations of $\mathrm{H}_{2} \mathrm{O}_{2}$ inhibit the activity of peroxidase in dye decoloration $^{21,51}$.

In conclusion, using the OFAT method, we determined that the CIP enzymatic activity assay was optimal at $25^{\circ} \mathrm{C}$ with $0.1 \mathrm{~mol} / \mathrm{L} \mathrm{NaAC}(\mathrm{pH} \mathrm{5.0)}$ buffer, 10 $\mathrm{mmmol} / \mathrm{L} \mathrm{H}_{2} \mathrm{O}_{2}, 0.5 \mathrm{mmol} / \mathrm{L} \mathrm{ABTS}$ and $49.7 \mathrm{ng} \mathrm{CIP.}$

The activity of CIP was $88 \mathrm{U} / \mathrm{mL}$ under these conditions.

Response surface analysis A 2-factor-5-level central composite design was adopted to optimize the assay mixture using the statistical software package "Design Expert 8.05 ". The experimental data were analyzed and fitted to a second order polynomial regression model described as follow: Activity $=87.99+31.05 \mathrm{~A}+23.18 \mathrm{~B}+$ $12.18 \mathrm{AB}-1.69 \mathrm{~A}^{2}-13.64 \mathrm{~B}^{2}$ where $\mathrm{A}$ is the concentration of ABTS, and $\mathrm{B}$ is the $\mathrm{H}_{2} \mathrm{O}_{2}$ concentration.

The analysis of variance for the quadratic polynomial model was summarized in Table 4. The model F-value of 48.36 ( $\mathrm{P}$ value $<0.0001$ ) implied that the model was significant and adequate to represent the actual relationships between the response (CIP activity) and the significant variables (ABTS concentration and $\mathrm{H}_{2} \mathrm{O}_{2}$ concentration). There was only a $0.01 \%$ chance that a model F-value could occur due to noise. The lack-of-fit p-value of 0.2264 indicated that the lack of fit was not significant relative to the pure error, and that the non-significant lack of fit was good. In this case, factor $\mathrm{A}$, factor $\mathrm{B}$, their combinant reaction and $\mathrm{B}^{2}$ were significant model terms (Table 4). The "Pred R-Squared" of 0.8583 was in reasonable agreement with the "Adj R-Squared" of 0.9518. "Adeq Precision" measured the signal to noise ratio. A ratio greater than 4 was desirable, and the ratio of 21.578 indicated an adequate signal.

Therefore, this model can be used to investigate the design space. The closer the values of adjusted $\mathrm{R}^{2}$ are to 1 , the better is the correlation between the experimental and predicted values ${ }^{46,52}$.

Table 4. Analysis of variance (ANOVA) for the quadratic regression model

\begin{tabular}{lllllll}
\hline Source & \multicolumn{2}{c}{ Sum of squares } & Df & Mean square & F value & P value \\
\hline Model & 13900.72 & 5 & 2780.14 & 48.36 & $<0.0001$ & Significant \\
A-A & 7713.50 & 1 & 7713.50 & 134.18 & $<0.0001$ & \\
B-B & 4300.00 & 1 & 4300.00 & 74.80 & $<0.0001$ & \\
AB & 593.01 & 1 & 593.01 & 10.32 & 0.0148 & \\
$A^{2}$ & 19.96 & 1 & 19.96 & 0.35 & 0.5742 & \\
$B^{2}$ & 1294.15 & 1 & 1294.15 & 22.51 & 0.0021 & \\
Residual & 402.39 & 7 & 57.48 & & & \\
Lack of fit & 252.05 & 3 & 84.02 & 2.24 & 0.2264 & \\
Pure error & 150.34 & 4 & 37.58 & & &
\end{tabular}

The effects of ABTS concentration, $\mathrm{H}_{2} \mathrm{O}_{2}$ concentration and their interaction on response values could be graphically presented as three dimensional response 
surface curves and contour plots (Fig. 5). CIP activity was enhanced with the increase in ABTS concentration and $\mathrm{H}_{2} \mathrm{O}_{2}$ concentration from 0 to $10 \mathrm{mmol} / \mathrm{L}$.

However, CIP activity decreased gradually when ABTS and $\mathrm{H}_{2} \mathrm{O}_{2}$ concentrations increased further. Too high or too low concentrations of ABTS and $\mathrm{H}_{2} \mathrm{O}_{2}$ would reduce the sensitivity of the enzyme activity assay. The highest enzyme activity was predicted as $139.073 \mathrm{U} / \mathrm{mL}$ by the "design expert 8.05 " software, with $16.36 \mathrm{mmol} / \mathrm{L}$ $\mathrm{H}_{2} \mathrm{O}_{2}$ and $0.82 \mathrm{mmol} / \mathrm{L}$ ABTS.
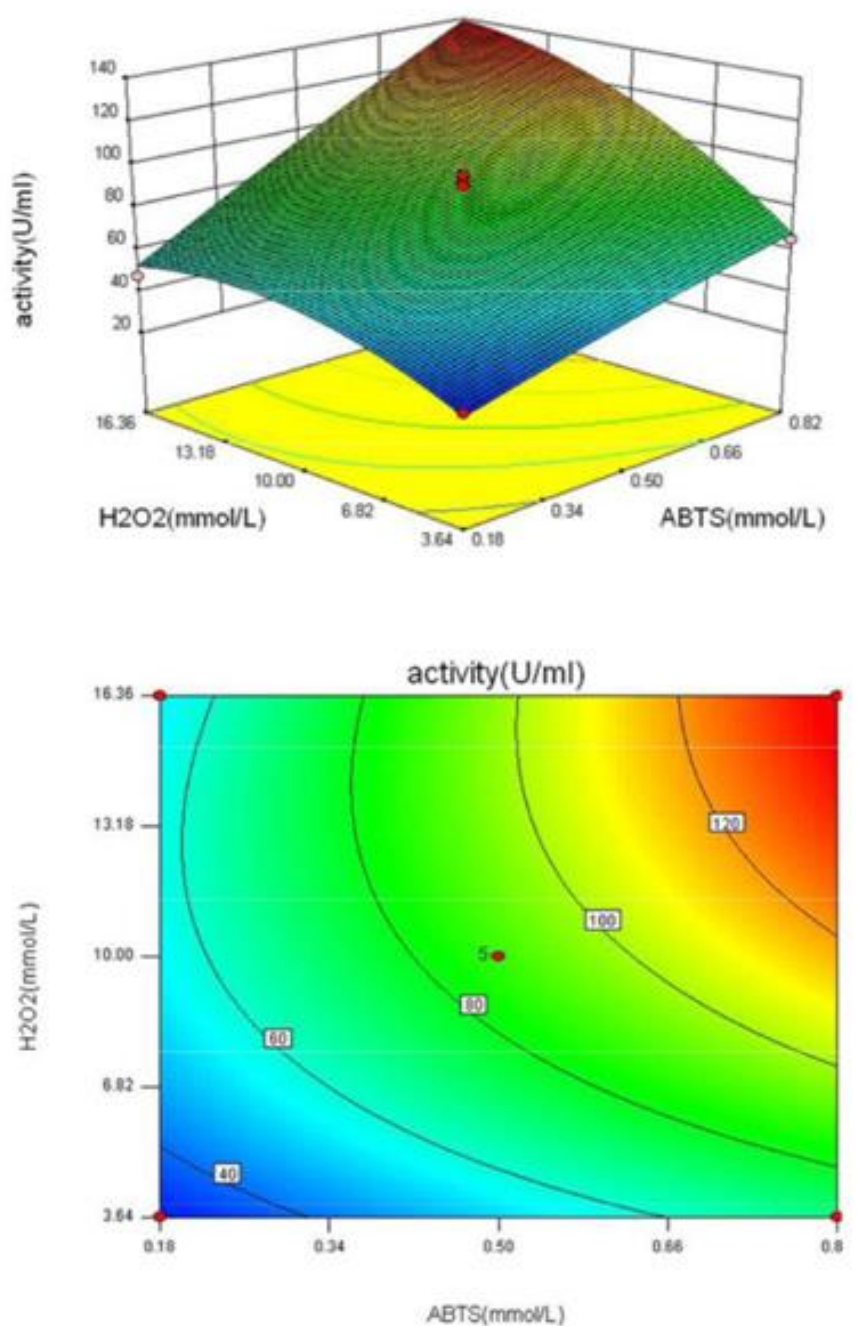

Figure 5. Response surface plot and contour plot of ABTS and $\mathrm{H}_{2} \mathrm{O}_{2}$ concentrations.

\section{Verification of optimal reaction condition}

To test the effectiveness and accuracy of the above model, enzyme activity assay was carried out at the predicted optimal conditions in triplicate, and the average enzyme activity was $138.89 \mathrm{U} / \mathrm{mL}$, which was quite close to the predicted value. The results indicated that the results of the theoretical analysis matched well with the experimental results, and that the optimization method for CIP assay was feasible based on the results of the response surface analysis. We also measured the CIP activity using the traditional ABTS method ${ }^{23}$, Chang's Guaiacol method ${ }^{32}$ and Sakurai's phenol method ${ }^{31}$, and the results showed that the activity of CIP was 46.24 $\mathrm{U} / \mathrm{mL}, 20.9 \mathrm{U} / \mathrm{mL}$ and $0.17 \mathrm{U} / \mathrm{mL}$, respectively. 


\section{CONCLUSIONS}

According to the kinetic parameters, ABTS was the best substrate. By using OFAT, we determined that the optimal reaction condition was $25^{\circ} \mathrm{C}, 0.1 \mathrm{~mol} / \mathrm{L} \mathrm{NaAC}(\mathrm{pH}$ 5.0), and $200 \mu \mathrm{l}$ mixture containing $0.5 \mathrm{mmol} / \mathrm{L} \mathrm{ABTS}, 10 \mathrm{mmol} / \mathrm{L} \mathrm{H}_{2} \mathrm{O}_{2}$ and 49.7 ng CIP, and the average CIP activity was $88 \mathrm{U} / \mathrm{mL}$ under these conditions. Furthermore, the optimal reaction mixture obtained from RSM was an initial ABTS concentration of $0.82 \mathrm{mmol} / \mathrm{L}, 49.7 \mathrm{ng} \mathrm{CIP}, 16.36 \mathrm{mmol} / \mathrm{L} \mathrm{H}_{2} \mathrm{O}_{2}$, and $25^{\circ} \mathrm{C}$. The maximum CIP activity was $138.89 \mathrm{U} / \mathrm{ml}$, which was 1.58 fold, 3 fold, 6.65 fold and 817 fold higher than that obtained using the OFAT method, the traditional ABTS method, the Guaiacol method, and the phenol method, respectively.

The model is adequate to represent the relationships between predicted values and experimental values.

\section{ACKNOWLEDGMENTS}

This work was financially supported by the National Natural Science Foundation of China (31300669), the Research Programs of Guangdong Province (2012B061800091, 2013A061402006 and 2014A020218012,2017B020202005), the Key Grant of Science and Technology Department of Henan Province (112102210385 and 142102210479), the Science Foundation for the High-level Talent of Nanyang Normal University (zx20110007) and the Scientific Research Fund of Henan Educational Committee (13A180811 and 14B180003), GDAS Special Project of Science and Technology Development (2017GDASCX-0107).

\section{REFERENCES}

1. Cerbo PD, Welinder KG, Schiødt CB. Kinetic evidence for surface residues influencing the active site of Coprinus cinereus peroxidase: analysis of the $\mathrm{pH}$ dependence of G154E, P90H and P90H-G154E substrate entrance mutants. Biochim Biophys Acta. 2001; 1544(1): 18-27.

2. Kim SJ, Lee JA, Kim YH, Song BK. Optimization of the functional expression of Coprinus cinereus peroxidase in pichia pastoris by varying the host and promoter. $J$ Microbio Biotechnol. 2009a; 19(9): 966-971.

3. Kim SJ, Joo JC, Kim HS, Kwon I, Song BK, Yoo YJ. Development of the radical-stable Coprinus cinereus peroxidase (CiP) by blocking the radical attack. J Biotechnol. 2014; 189(1): 78-85.

4. Neri F, Indlani C, Welinder KG, Smulevich G. Mutation of the distal arginine in Coprinus cinereus peroxidase structural implications. Eur J Biochem. 1998; 251: 830-838.

5.Abelskov AK, Smith AT, Rasmussen CB, Dunford HB, Welinder KG. pH Dependence and structural interpretation of the reactions of Coprinus cinereus peroxidase with hydrogen peroxide, ferulic acid, and 2,2-Azinobis (3-ethylbenzth iazoline- 6-sulfonicacid). Biochem. 1997; 36(31): 9453-9463.

6.Shinmen Y, Asami S, Amachi T, Shimizu S, Yamada H. Crystallization and characterization of an extracellular fungal peroxidase. Agric Biol Chem. 1986; 50(1): $247-$ 249.

7.Andersen MB, Hsuanyu Y, Welinder KG, Schneider P, Dunford HB. Spectral and kinetic properties of oxidized intermediates of Coprinus cinereus peroxidase. Acta Chim Scand. 1991; 45: 1080-1086.

8.Kjalke M, Andersen MB, Schneider P, Christensen B, Schülein M, Welinder KG. Comparison of structure and activities of peroxidases from Coprinus cinereus, Coprinus macrorhizus and Arthromyces ramosus. Biochim Biophys Acta. 1992; 1120(3): 248-256. 
9.Kim SJ, Lee JA, Joo JC, Yoo YJ, Kim YH, Song BK. The development of a thermostable $\mathrm{CiP}$ (Coprinus cinereus peroxidase) through in silico design. Biotechnol Prog. 2010; 26(4): 1038-1046.

10. Ryu K, Mceldoon JP, Dordick JS. Kinetic characterization of a fungal peroxidase from Coprinus cinereus in aqueous and organic media. Biocatal Biotransform. 2009; 13(1): 5363.

11. Ikehata K, Buchanan ID, Smith DW. Treatment of oil refinery wastewater using crude Coprinus cinereus peroxidase and hydrogen peroxide. J Environ Eng Sci. 2003; 2(4): 463-472.

12. Kauffmann C, Petersen BR, Bjerrum MJ. Enzymatic removal of phenols from aqueous solutions by Coprinus cinereus peroxidase and hydrogen peroxide. J Biotechno. 1999; 73(1): 71-74.

13. Mao XJ, Buchanan ID, Stanley SJ. Phenol removal from aqueous solution by fungal peroxidase. J Environ Eng Sci. 2006; 5: s103-s109.

14. Pezzotti F, Okrasa K, Therisod M. Oxidation of chlorophenols catalyzed by Coprinus cinereus peroxidase with in situ production of hydrogen peroxide. Biotechnol Prog. 2004; 20(6): 1868-1871.

15. Sakurai A, Toyoda S, Sakakibara M. Removal of bisphenol A by polymerization and precipitation method using Coprinus cinereus peroxidase. Biotechnol Lett. 2001; 23(12): 995-998.

16. Sarkhanpour R, Tavakoli O, Sarrafzadeh MH, Kariminia HR. The comparision of Coprinus cinereus peroxidase enzyme and $\mathrm{TiO}_{2}$ catalyst for phenol removal. J Environ Sci Heal A. 2013; 48(3): 300-307.

17. Patapas J, Al-Ansari MM, Taylor KE, Bewtra JK, Biswas N. Removal of dinitrotoluenes from water via reduction with iron and peroxidase-catalyzed oxidative polymerization: a comparison between Arthromyces ramosus peroxidase and soybean peroxidase. Chemosphere. 2007; 67(8): 1485-1491.

18. Rūta IG, Juozas K. Effects of rhamnolipid biosurfactant JBR425 and synthetic surfactant surfyno1465 on the peroxidase-catalyzed oxidation of 2-naphthol. J Environ Sci-China. 2013; 25(7): 1431-1440.

19. Moutaouakkil A, Blaghen M. Decolorization of the anthraquinone dye cibacron blue 3GA with immobilized Coprinus cinereus in fluidized bed bioreactor. Appl Biochem Microbiol. 2011; 47(1): 59-65.

20. Majoumered MM, Kariminia H-R. Bisubstrate kinetic model for enzymatic decolorization of reactive black 5 by Coprinus cinereus Peroxidase. Iran J Chem Chem Eng. 2013; 32(2): 125-134.

21. Yousefi V, Kariminia HR. Statistical analysis for enzymatic decolorization of acid orange 7 by Coprinus cinereus peroxidase. Int Biodeterior Biodegrad. 2010; 64(3): 245-252.

22. Kim YH, Won K, Kwon JM. Jeong HS, Park SY, An ES. Synthesis of polycardanol from a renewable resource using a fungal peroxidase from Coprinus cinereus. J Mol Catal B Enzym. 2005; 34(1): 33-38.

23. Kim YH, An ES, Park SY, Lee JO, Kim JH, Song BK. Polymerization of bisphenol a using Coprinus cinereus peroxidase and its application as a photoresist resin. J Mol Catl B Enzym. 2007; 44(3-4): 149-154.

24. Kim YH, An,ES, Song BK. Co-polymerization of MTPC(methylenetri p-cresol) and mcresol using $\mathrm{CiP}$ (Coprinus cinereus peroxidase) to improve the dissolution characteristics of the enzyme-catalyzed polymer. J Mol Catal B Enzym. 2009b; 56(4): 227-230.

25. Park JC, Joo JC, An ES, Song BK, Kim YH, Yoo YJ. A combined approach of experiments and computational docking simulation to the Coprinus cinereus peroxidasecatalyzed oxidative polymerization of alkyl phenols. Bioresour Technol. 2011; 102(7): 4901-4904.

26. Park SY, Kim YH, Won K, Song BK. Enzymatic synthesis and curing of polycardol from renewable resources. J Mol Catal B Enzym. 2009; 57(1): 312-316.

27. Fágáin CÓ. Enzyme stabilization-recent experimental progress. Enzyme Microb Tech. 2003; 33(2-3): 137-149. 
28. Savizi ISP, Kariminia HR, Ghadiri M, Roosta-Azad R. Amperometric sulfide detection using Coprinus cinereus peroxidase immobilized on screen printed electrode in an enzyme inhibition based biosensor. Biosens Bioelectron. 2012; 35(1): 297-301.

29. Cherry JR, Lamsa MH, Schneider LP, Vind J, Svendsen A, Jones A. Directed evolution of a fungal peroxidase. Nat Biotechnol. 1999; 17(4): 379-384.

30. Tams JW, Vind J, Welinder KJ. Adapting protein solubility by glycosylation.: NGlycosylation mutants of Coprinus cinereus peroxidase in salt and organic solutions. Biochim Biophys Acta. 1999; 1432: 214-221.

31. Sakurai A, Kawamoto S, Abarca J, Sakakibara M. Peroxidase production by Coprinu scinereus using rotating disk contactor. Biochem Eng J. 2002; 110(1): 47-53.

32. Chang HC, Holland RD, Bumpus JA., Churchwell MI, Doerge DR. Inactivation of Coprinus cinereus peroxidase by 4-chloroaniline during turnover: comparison with horseradish peroxidase and bovine Lactoperoxidase. Chem-Biol Interact. 1999; 123: 197217.

33. Kamiya N, Nagamune T. Effect of water activity control on the catalytic performance of surfactant-Arthromyces ramosus peroxidase complex in toluene. Biochem Eng J. 2002; 10(1): 55-59.

34. Li XD, Jia R, Li PS, Ang SS. Response surface analysis for enzymatic decolorization of Congo red by Manganese peroxidase. J Mol Catal B Enzym. 2009; 56(1): 1 - 6.

35. Hwang IW, Chung SK, Jeong MC, Chung HS, Zheng HZ. Optimization of enzymatic hydrolysis of persimmon peels for vinegar fermentation. J Korean Soc Appl Biol Chem. 2013; 56(4): 435-440.

36. Kumar P, Satyanarayana T. Optimization of culture variables for improving glucoamylase production by alginate-entrapped thermomucor indicaeseudaticae using statistical methods. Bioresour Technol. 2007; 98: 1252-1259.

37. Mohammad P, Azarmidokht H, Fatollah M, Mahboubeh B. Application of response surface methodology for optimization of important parameters in decolorizing treated distillery wastewater using Aspergillus fumigates UB2.60. Int Biodeterior Biodegrad. 2006; 57(2): 195-199.

38. Chakraborty SK, Singh DS, Kumbhar BK, Singh D. Process parameter optimization for textural properties of ready-to-eat extruded snack food from millet and legume pieces blends. J Texture Stud. 2009; 40 (6): 710-726.

39. Shieh CJ, Lou YH. Five-factor response surface optimization of the enzymatic synthesis of citronellyl butyrate by lipase IM77 from Mucor miehei. JAOCS 2000; 77(5): 521-525.

40. Vijayalakshmi G, Shobha B, Vanajakshi V, Divakar S, Manohar B. Response surface methodology for optimization of growth parameters for the production of carotenoids by a mutant strain of Rhodotorula gracilis. Eur Food Res Techno. 2001; 213(3): 234-239.

41. Coman G, Bahrim G. Optimization of xylanase production by Streptomyces sp. P12-137 using response surface methodology and central composite design. Ann Microbiol. 2011; 61(4): 773-779.

42. Liu C, Sun ZT, Du JH, Wang J. Response surface optimization of fermentation conditions for producing xylanase by Aspergillus niger SL-05. J Ind Microbiol Biotechnol. 2008; 35(7): 703-711.

43. Li CJ, Zhang X, Zhang LP, Wang A, Mao RQ, Li G. Medium optimization for the production of a metagenome-derived $\beta$-galactosidase by Pichia pastoris using response surface methodology. Afr J Microbiol Res. 2013; 7(13): 1077-1085.

44. Li HJ, Song CL, Zhou HM, Cao D. Optimization of the aqueous enzymatic extraction of wheat germ oil using response surface methodology. J Am Oil Chem Soc. 2011; 88: 809817.

45. Zheng Y, Quan J, Zhu LM, Jiang B, Nie HL. Optimization of selective lipase-catalyzed feruloylated monoacylglycerols by response surface methodology. J Am Oil Chem Soc. 2008; 85(7): 635-639.

46. Zhang HC, Yu LN, Yang QL, Sun J, Bi J, Liu SF, et al. Optimization of a microwavecoupled enzymatic digestion process to prepare peanut peptides. Molecules. 2012; 17(5): 5661-5674.

47. Mumtaz MW, Adnan A, Anwar F, Mukhtar H, Raza MA, Ahmad F, et al. Response surface methodology: an emphatic tool for optimized biodiesel production using rice bran and sunflower oils. Energies. 2012; 5(9): 3307-3328. 
48. Alam MZ, Mansor MF, Jalal KCA. Optimization of decolorization of methylene blue by lignin peroxidase enzyme produced from sewage sludge with Phanerocheate chrysosporium. J Hazardous Materials. 2009; 162(2-3): 708-715.

49. Ikehata K, Buchanan ID, Pickard MA, Smith DW. Purification, characterization and evaluation of extracellular peroxidase from two Coprinus species for aqueous phenol treatment. Bioresour Technol. 2005; 96(16): 1758-1770.

50. Ward G, Belinky PA, Hadar Y, Bilkis I, Dosoretz CG. The influence of non-phenolic mediators and phenolic co-substrates on the oxidation of 4-bromophenol by lignin peroxidase. Enzyme Microb Technol. 2002; 30(1): 490-498.

51. de Silva MR, de Sá L, Russo C, Scio E, Ferreira-Leitao VS. The use of HRP in decolorization of reactive dyes and toxicological evaluation of their products. Enzyme research. 2010: 703-824.

52. Zhou B, Wang JF, Pu YW, Zhu MJ, Liu SM, Liang SZ. Optimization of culture medium for yellow pigments production with monascus anka mutant using response surface methodology. Eur Food Res Technol. 2009; 228(6): 895-901. 